\title{
Wage Inequality and Establishment Heterogeneity
}

\author{
In Kyung Kim* $\quad$ Jozef Konings ${ }^{\dagger}$
}

March 2019

\begin{abstract}
We analyze wage dispersion within and across establishments in Korea between 2007 and 2013. We find that foreign owned establishments and those operating in global markets have higher within establishment wage dispersion. The effect is over and above the establishment size effect. Further- more, wages are higher in larger establishments and internationally oriented ones. Our findings are consistent with theories explaining management pay and the scope of control. Our results also pro- vide evidence that can explain the rise in wage inequality due to the emergence of 'super star' firms and global supply chains.
\end{abstract}

Keywords: wage inequality, managerial talent, globalization

JEL Classification Numbers: F16, J31

${ }^{*}$ Corresponding author, Department of Economics, Nazarbayev University, Astana 010000, Kazakhstan, E-mail: in.kim@nu.edu.kz.

${ }^{\dagger}$ Department of Economics, University of Liverpool Management School, Chatham St, Liverpool L69 7ZH, UK and Department of Economics, University of Leuven, E-mail: joep.konings@kuleuven.be. This paper is part of the GROWINPRO project of EU horizon 2020 program, No. 822781. 


\section{Introduction}

In recent years, there has been a fast growing literature documenting the increase in income in- equality across the world (Atkinson et al., 2011). An important concern largely ignored by most trade economists is that the gains of globalization have not benefited all in the same way. For instance, Autor et al. (2013) document how import competition from China has contributed to almost 3 million jobs lost in U.S. manufacturing between 2000 and 2010. Goos et al. (2009) show how offshoring has contributed to increased polarization in the U.K.. With the emergence of 'super star' firms ${ }^{1}$ operating along global supply chains, increased scale economies related to international trade have likely resulted in increased profits of multinational firms with limited pass-through into prices and wages (Goldberg and Pavcnik, 2016). This is in line with recent evidence showing the increased market power in U.S. listed firms during the last 4 decades (De Loecker and Eeckhout, 2017).

This paper analyzes the role of establishment heterogeneity in rising wage inequality. In particular, there are large differences between establishments in terms of their size and hence profitability even withinnarrowly defined sectors. Establishments also differ in terms of their participation to international trade or international production networks. We use a new and hitherto unexploited establishment level data set of Korean firms with detailed information on different occupational hierarchies and their wages to analyze how establishment size and exposure to international trade may have contributed to wage dispersion within and across establishments.

A number of papers has studied the sources of wage inequality around the world. One strand of the literature has documented increasing wage inequality due to trade liberalization in both developed and developing economies (Goldberg and Pavcnik, 2007, Verhoogen, 2008). However, the evidence of the impact of trade on inequality for the Korean case seems to be mixed. Kang (2014) studies the impact of trade openness and FDI on the income distribution and finds that trade openness is positively related to income inequality, but negatively related to FDI inflows and outflows. Lee (2017) shows that import competition and technological change contributed to rising wage dispersion within the manufacturing sector over 1980-2012. However, other traderelated measures, such as export intensity and FDI had no substantial effects on wage inequality. In contrast, Karacaovali and Tabakis (2017) document that a significant part of the aggregate wage inequality persists within different trade-exposure categories in manufacturing and services sectors, suggesting that international trade might not be the main factor to explain rising wage dispersion.

Another strand of the literature has studied wage policies that pay out high wages to CEOs as a source of growing earnings inequality. However, as argued by Mueller et al. (2017a,b), the rise of CEO pay over the last decades alone cannot explain the increased aggregate wage inequality; CEO pay typically lies well above the 90 th percentile, whereas the aggregate rise in inequality is often measured as the $90 / 10 \log$ wage inequality. Therefore, if wage inequality between different occupations within the firm has also increased, ${ }^{2}$ then this may be an important factor explaining overall wage inequality in a country. The theoretical literature explaining variation in CEO pay may 
well be extended as is done by Mueller et al. $(2017 \mathrm{a}, \mathrm{b})$ to the dispersion in wages between occupations within firms. Gabaix and Landier (2008) show that CEO pay depends on the size of its firm, which captures the amount of resources under his control. More talented

\footnotetext{
'Autor et al. (2017) offer a number of explanations for the rise of 'super star' firms such as the rise of software platforms and the internet, the global supply chains and network effects favoring firms that are better in adapting and exploiting new modes of (international) production and organization.

${ }^{2}$ Autor and Dorn (2013) for the U.S., Goos et al. (2009) for the U.K., and Breemersch et al. (2017) for various OECD countries show that wage polarization across various occupations seems to be a widespread stylized fact of the last few decades.
} 
CEOs are matched with larger firms, resulting in a positive relationship between firm size and CEO pay (Terviö, 2008). Hence, if more talented managers are matched with larger firms, we should expect to see a positive relationship between firm size and not only CEO pay, but also with pay of other managers along the hierarchy of the firm.

If the wage dispersion increases with the firm size, then the emergence of 'super star firms' that dominate the market in terms of output, employment and exports can only have contributed to the increased wage dispersion. ${ }^{3}$ De Loecker and Eeckhout (2017) show that market power in the U.S. has been rising over the last four decades due to the increasingly growing role of large and dominant firms, resulting in increasing dispersion in profits and a decline in the labor share in the U.S.. Budd et al. (2005) have shown that international rent-sharing between affiliate and parent profits of multi- national enterprises can indeed contribute to the rising wage inequality, and as production has become increasingly international over the last decades, this channel has become more important as a driver of observed wage inequality. Similarly we can expect that as the scope of the firm has been growing within the global economy and with increasing technological challenges, the wage dispersion within and across firms has also increased.

In this paper we first document within establishment wage dispersion that cuts across different hierarchies. we then analyze to what extent the wage dispersion within and across establishments is explained by establishment size and its global nature, both capturing the scope of control required by not only the CEO but also lower management functions. To this end, we consider two proxies that measure the global nature of the establishment; the export intensity and the fraction of foreign owned shareholders.

\section{Data}

The data used in the analysis is the Workplace Panel Survey by Korea Labor Institute. It is establishment level biennial survey from 2007 to 2013. The population of all establishments with 30 or more employees in Korea is partitioned into 240 strata based on industry classification, establishment size, and region. ${ }^{4}$ Then, the establishments in this survey are selected based on the stratified random

\footnotetext{
${ }^{3}$ For instance, firm size distributions in terms of sales, employment, exports and imports, follow a power law. Take exports as an example, in most countries 90 percent of exports is concentrated in the top 10 percent of exporting firms and the largest exporters tend to be the largest imports (Amiti et al. (2014)).

${ }^{4}$ The population excludes establishments in agriculture, fisheries, mining industries, whose combined share of GDP is 2 percent.
} 
sampling, giving larger sampling fraction to larger establishments. ${ }^{5}$

Within each establishment we have wage information on three categories of workers; new recruit, section chief, and department head. ${ }^{6}$ By definition, more managerial talent is required to department heads than section chiefs, who in turn are expected to have more managerial talent than new recruits. While the data report only on three broad hierarchies within the establishment, the information on compensation that workers receive includes both basic employee pay and bonuses, which is potentially an important aspect of the package that especially managers receive. Closely related to our approach is the work of Mueller et al. (2017a,b). They use U.K. firm level data with information on more hierarchal levels within the firm, but only with basic pay. We calculate three wage ratios, $r 12, r 13$, and $r 23$, where rij represents the wage ratio of the $j$-th rank to the $i$-th rank, and the $j$-th rank is higher than the $i$-th

rank. For example,

$$
r 12=\frac{\text { Average Wage for Section Chief }}{\text { Average Wage for New Recruit }}
$$

An important feature of the data is that it contains information on the global nature of the estab- lishment. In particular, we know the fraction of exports in total sales, which allows us to distinguish between exporters versus domestic oriented establishments. Typically, exporters are more productive (Bernard et al., 2014) and the scope of control in them is larger as they serve various export markets, which would be reflected in the compensation packages. In addition, we have firm level information on the ownership share of foreign investors. This allows us to distinguish between multinational firms and domestic ones. As multinational enterprises are typically larger, more profitable, active in many international markets and tend to have better management practices (Bloom et al., 2012), we expect that the compensation packages for different hierarchies would be adjusted accordingly.

Finally, the data provides operational and financial information on various indicators such as sales, total assets, profits, and employment. ${ }^{7}$ In our analysis we only consider establishments that report information on establishment level compensation for all three levels of hierarchies. This resulted in removing 20 percent of our observations, leaving a sample of 5,654 observations on 2,166 establishments (see data appendix for details). About half of them belong to the manufacturing sector, with the rest spread across construction, retail, transport and business services.

\footnotetext{
${ }^{5}$ For example, only 11.7 percent of establishments with 30-99 employees in the construction sector are selected, whereas the sampling fraction goes up to 71.4 percent for establishments with 500 or more employees in the same sector.

${ }^{6}$ For section chief and department head, it is the average first year wage for the major type of job in the establishment. For example, if the major activity is manufacturing, then the average first year wage of section chiefs and department heads only in that occupation is reported.

${ }^{7}$ Some information is only available at the firm level, while other information at the establishment level. Details are
} 
Figure 1: Skewed size and export distribution in 2007.
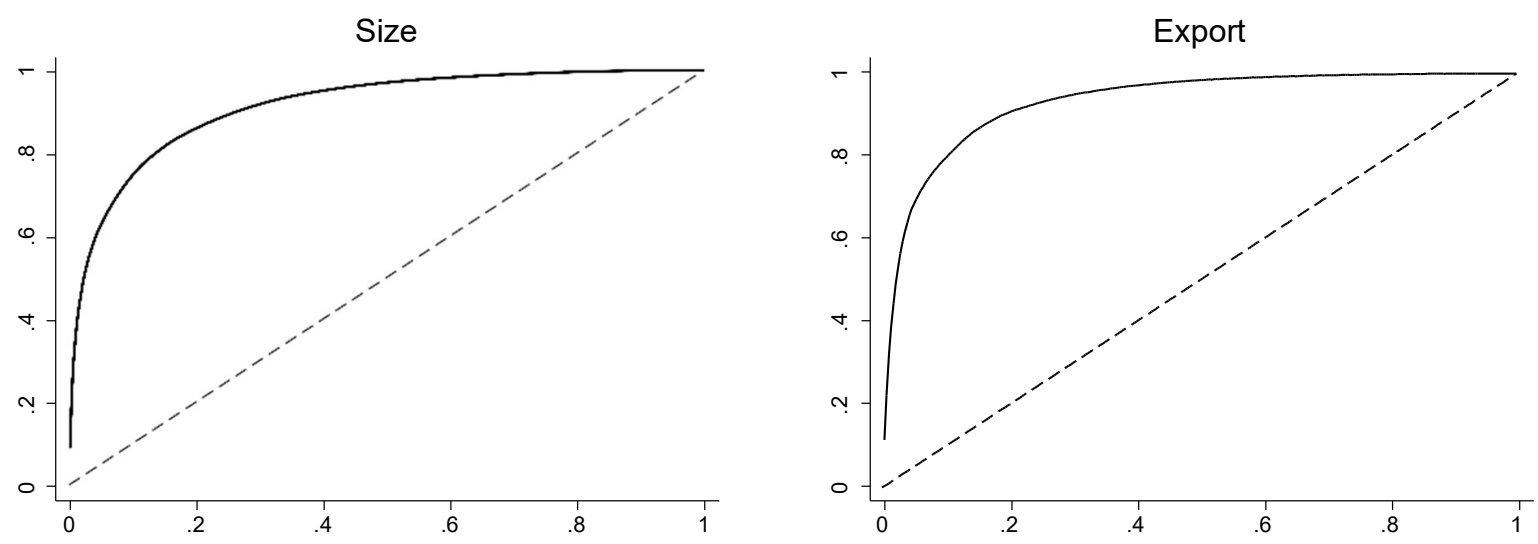

Note: The left (right, respectively) panel plots Lorenz curve using total asset (export, respectively) of establish- ments in 2007. Establishments with no export are excluded in the right panel.

Table 1 presents descriptive statistics for the key variables of the analysis. There exists substantial wage dispersion in the average establishment; relative to the wage of a new recruit, which is on average 24 thousand USD a year, the department head earns 90 percent more. A section chief earns on average 50 percent more than a new recruit, and the department head earns 30 percent more on average than a section chief. Comparing the average and median of the size measures reveals that the distribution of establishment size is right skewed and there is a lot of heterogeneity in terms of size. This is also shown in the left panel of Figure 1 where we plot the Lorenz curve of total assets. Only 20 percent of the establishments account for about 80 percent of all total assets in the sample. This indicates the presence of a few dominant establishments with a large fringe of small ones. If 'super star' firms play a role in increased wage inequality we would expect that wage dispersion in these dominant and large establishments would be higher.

Note also that on average 12 percent of sales are exports, while the average foreigners' ownership share in the sample is 5 percent. $^{8}$ This low degree of internationalization is mainly due to the fact that most establishments are not exporting at all or owned entirely by domestic shareholders. For instance, Table 2 shows that 64 percent of establishments $(3,593$ out of 5,654$)$ does not export their products. Moreover, the export share is less than 50 percent in 1,425 establishments ( 25 percent) and only 11 percent of establishments export 50 percent or more of their products. When we plot the distribution

provided in the data appendix.

${ }^{8}$ The correlation coefficient of foreign market share and foreigners' ownership share is 0.22 . 
of exports in Figure 1 it is clear that exports is also concentrated in a few top exporters. We explore how this heterogeneity may have contributed to increased wage dispersion in the next sections.

\section{Wage Inequality and Establishment Heterogeneity}

\section{Larger wage dispersion at larger and more internationalized establishments}

We start the empirical analysis with examining whether the wages for employees of different ranks are more dispersed in larger and more internationalized establishments. We focus on two key drivers of wage dispersion within establishments. As has been shown in the literature on CEO compensation and more generally by Mueller et al. (2017b), the larger the scope of control of managers, the higher the required compensation. Most papers have measured the scope of control by firm size only. However, since firm size typically refers to employment or total assets in one particular country, it does not capture other important dimensions of the scope of the firm. In particular, firm size might poorly capture the scope of control managers are required to deal with when its main markets are foreign or when it is part of a multinational group. There may even be firms that have a relatively small activity in a particular country, while most of its activities are taking place abroad. We therefore measure the scope of control of management in the establishment by its export orientation and multinational nature in addition to its size.

We seek to estimate the following empirical relation of wage dispersion within the establishment: $\ln r_{i t}=\alpha$

$$
+\beta \ln \text { Size }_{i t}+\gamma_{1} 1[E X<50]_{i t}+\gamma_{2} 1[E X \geq 50]_{i t}+\mathbf{x}_{i t} \delta+\psi_{s}+\psi_{s t}+\varepsilon_{i t},
$$

where subscripts $i, s$, and $t$ represent establishment, sector, and year, respectively. We use the log of the three wage ratios $(r 12, r 13$, and $r 23)$ as the dependent variable one by one. $\ln$ Size is the log of the establishment size measured by its total asset. Given that most establishments do not export and only for few firms the export share exceed 50 percent, we discretize the internationalization degree and define two binary variables: binary variable $1[E X<50](1[E X \geq 50]$, respectively) is equal to 1 if the proportion of the export in total sales of the establishment is between 0 and 50 percent (50 percent or more, respectively), and zero otherwise. ${ }^{9}$

The vector $\mathbf{x}$ includes the following observable establishment characteristics: the log of the estab- lishment age, the organizational type (incorporated, individual, etc.), and the management type (family

\footnotetext{
${ }^{9}$ Hence, no export is the omitted category.
} 
managed, professionally managed, etc.). Sector fixed effect $\psi_{s}$ controls for unobservable sector-specific factors that may affect the wage dispersion, while year-sector fixed effect $\psi_{\text {st }}$ controls for unobservable year-specific shocks whose effects are uniform across establishments within the same sector.

We first estimate model (1) without the two indicators of export orientation. From columns (1), (4), and (7) of Table 3, we see that wage dispersion is larger in larger establishments. For instance, the pay associated with the section chief increases by 0.01 percent relative to the pay associated with the new recruit when the establishment size increases by one percent. For the department head the pay increases by 0.018 percent compared to the new recruit. Hence, increase in establishment size has a larger impact on wage ratio $r 13$ than on wage ratio $r 12$. With only three hierarchal levels available in our sample data we cannot explore further differences, but the pattern we find is consistent with Mueller et al. (2017b) that analyze U.K. data on more levels of hierarchies. ${ }^{10}$

We next analyze whether there is an effect over and above the size effect, which can be attributed to the international orientation of the establishment. The results are reported in columns (2), (5), and (8) of Table 3, where we add the two indicators of export orientation. We find evidence that more export intensive establishments exhibit higher wage inequality, especially between the department head and other two lower ranks. The wage ratio between the department head and section chief (the wage ratio between the department head and new recruit, respectively) in an establishment with heavy export, that is, the proportion of the export is at least 50 percent, is 2.5 percent (3.2 percent, respectively) higher than in an establishment with no export.

Instead of the export proportion, we use the foreigners' ownership share as an alternative measure of internationalization of the establishment in model (1): a dummy variable $1[F S<50]$ (1[FS $\geq 50]$, respectively) is equal to 1 if the foreigners' ownership share of the firm is between 0 and 50 percent (greater than or equal to 50 percent, respectively), and zero otherwise. Estimation results presented in columns (3), (6), and (9) of Table 3 show that the higher the foreigners' ownership share, the higher the relative wage for department head. However, the evidence is not statistically significant.

\section{Higher wage at larger and more internationalized establishments}

While the size and international orientation of the establishment seem to have a positive impact on within establishment wage dispersion, a related issue is whether larger and more internationally oriented

\footnotetext{
${ }^{10}$ They analyze 9 different levels and find for instance that one percent increase in firm size is associated with 3.8 percent increase in the pay ratio between the lowest rank and rank 6 . This goes up to 17.9 percent for the pay ratio between the highest and lowest levels in the firm.
} 
establishments also pay higher wages. In other words, establishment heterorgeneity not only contributes to within establishment wage dispersion, but it may also explain wage dispersion across establishments. If more internationally oriented establishments require more talented workers given the larger scope of control, typical efficiency wage considerations could result in higher starting wages in the first place. Or if multinational enterprises and international active establishments engage in more rent sharing, given their higher profits on average, we would expect higher initial wages (Budd et al., 2005). We examine this by analyzing the wage of the three hierarchal levels. We use the same specification as in (1), but use as the dependent variable, the log of the three wage levels one by one.

In Table 4 we note that the average wage is higher in larger establishments for all hierarchies. For example, results in the first column shows that one percent increase in establishment size increases the wage of new recruits by 0.055 percent. If we take the establishment at the 75 th percentile of the distribution of the total assets (55 million dollars) and compare it to the establishment at the 25th percentile of the distribution (5.5 million dollars), this estimate implies that the wage of the new recruit would be 44 percent higher in the former. Also, we find evidence that the wages of all hierarchies are higher in exporting establishments and in multinational enterprises. For example, according to results in column (8) an establishment whose export share is 50 percent or more pays 4.3 percent higher wage to its section chiefs than an establishment without any sales abroad.

These results suggest that an important source of the observed wage inequality can be explained by the observed heterogeneity between establishments in terms of size and international orientation. Given the highly skewed size distribution that can be observed in most economies and the emergence of so called 'super star' firms in the last couple of decades, size seems an important source that can explain the rise in wage inequality and polarization. Furthermore, the increasing globalization and dominance of internationally oriented firms seem to have added to this general trend of wage inequality and polarization. This effect is over and above the pure size effect.

\section{Robustness}

We carry out a number of robustness checks. First, we exploit the within-establishment variations to examine how the size and internationalization of an establishment is associated with its wage dispersion and wage level. For this purpose, we replace the sector fixed effects with the establishment fixed effects in model (1). The potential endogeneity bias would be controlled for to the extent that establishment size and degree of internalization is correlated with unobservable time-varying sector specific-shocks or 
time-invariant establishment-specific factors. Also, in the model we use the export proportion itself rather than splitting it into the two dummies $\left(1[E X<50]_{i t}\right.$ and $\left.1[E X \geq 50]_{i t}\right)$, expecting that it would capture the globalization of the establishment better. This is because the change of an establishment's export share over years would be rather continuous. Within estimators in Table 5 show that the relative wage for higher ranks increases as the establishment grows. Also, the more the establishment exports and the higher the foreigners' ownership share, the larger its wage dispersion is. For example, results in column (5) reveal that when the export proportion grows from zero to 50 percent, the wage ratio between the department head and new recruit increases by 4.1 percent. According to the estimation results reported in Table 6, only the wage of department heads increases in response to the growth of the establishment. Specifically, it rises by 0.035 percent if the establishment size grows by 1 percent. Also, we find evidence that the wages of the section chiefs and department heads are positively affected by the internationalization of the establishment.

Next, instead of the total asset we use other measures of the establishment size - sales and number of employees - one by one in model (1). Estimates in Tables 7 and 8, where the establishment size is measured by sales of the establishment, are qualitatively the same as previous findings; establishments with larger size, more export, and higher foreigners' ownership share are more likely to have larger wage dispersion as well as paying higher wages to employees. We find similar results when number of employees is used instead as the proxy for the establishment size as is reported in Tables 9 and 10.

Lastly, to check whether our results are driven by the outliers we drop observations that belong to the lower and upper 5 percentile in terms of the establishment size. The results reported in Tables 11 and 12 are similar to those without dropping outliers.

\section{Conclusion}

This paper has looked at the role of establishment heterogeneity as a new channel for explaining wage inequality and polarization in the labor market, using a new data set of Korean establishments. We find that a typical department head would earn almost twice as much as a new recruit and one third more than a section chief. This within establishment wage inequality increases with its size, resulting in higher wage dispersion in larger establishments. We also find a positive impact of international- ization on wage inequality. In particular, export intensive establishments and establishments that are part of a multinational tend to have higher wage dispersion amongst different hierarchies within the 
establishment.

Furthermore, heterogeneity between establishments also explains observed wage differences across establishments. Larger establishments and multinationals pay more than domestic and small ones. The rise of so called 'super star' firms that are often operating along complex global supply chains, taking an increasingly dominant role in the market, suggests that the gains from globalization do not seem to benefit all workers equally.

\section{References}

Mary Amiti, Oleg Itskhoki, and Jozef Konings. Importers, exporters, and exchange rate disconnect. The American Economic Review, 104(7):1942-1978, 2014.

Anthony B Atkinson, Thomas Piketty, and Emmanuel Saez. Top incomes in the long run of history. Journal of economic literature, 49(1):3-71, 2011.

Baybars, Karacaovali and Chrysostomos Tabakis. Wage inequality dynamics and trade exposure in South Korea. Journal of Asian Economics 48: 48-65, 2017.

David. Autor and David Dorn. The growth of low-skill service jobs and the polarization of the us labor market. The American Economic Review, 103(5):1553-1597, 2013.

David Autor, David Dorn, Lawrence Katz, Christina Patterson, and John Van Reenen. Concentrating on the fall of the labor share. American Economic Review: Papers and Proceedings, 107:180-185, 2017.

David H Autor, David Dorn, and Gordon H Hanson. The china syndrome: Local labor market effects of import competition in the united states. The American Economic Review, 103(6):2121-2168, 2013.

Andrew B Bernard, Ilke Van Beveren, and Hylke Vandenbussche. Multi-product exporters and the margins of trade. The Japanese Economic Review, 65(2):142-157, 2014.

Nicholas Bloom, Raffaella Sadun, and John Van Reenen. Americans do it better: Us multinationals and the productivity miracle. The American Economic Review, 102(1):167-201, 2012.

Myeong-Joo Kang. The Study on the Effect of Trade Openness and FDI on Income Distribution. International Commerce and Information Review, 16(4), 151-167, 2014.

Koen Breemersch, Joze. Damijan, and Jozef Konings. Labor market polarization in advanced coun- tries: impact of global value chains, technology, import competition from china and labor market institutions, 2017. OECD Working Paper.

John Budd, Jozef Konings, and Matthew Slaughter. Wages and international rent sharing in multina- tional firms. The Review of Economics and Statistics, 87(1):73-84, 2005.

Siwook Lee. International trade and within-sector wage inequality: The case of South Korea. Journal of Asian Economics 48: 38-47, 2017.

Jan De Loecker and Jan Eeckhout. The rise of market power and the macroeconomic implications. Working Paper 23687, National Bureau of Economic Research, August 2017.

Xavier Gabaix and Augustin Landier. Why has ceo pay increased so much? The Quarterly Journal of Economics, 123(1):49-100,2008.

Pinelopi K Goldberg and Nina Pavcnik. Distributional effects of globalization in developing countries. Journal of economic Literature, 45(1), 39-82, 2007. 
Pinelopi K Goldberg and Nina Pavcnik. The effects of trade policy. Handbook of Commercial Policy, 1:161206, 2016.

Maarten Goos, Alan Manning, and Anna Salomons. Job polarization in europe. The American Economic Review, 99(2):58-63,2009. 
Holger Mueller, Paige Ouimet, and Elena Simintzi. Wage inequality and firm growth. American Economic Review: Papers and Proceedings, 107(5):379-383,2017a.

Holger Mueller, Paige Ouimet, and Elena Simintzi. Within-firm pay inequality. The Review of Financial Studies, pagehhx032, 2017b.

Marko Terviö. The difference that ceos make: an assignment model approach. The American Economic Review, 98(3):642-668,2008.

Eric A Verhoogen Trade, quality upgrading, and wage inequality in the Mexican manufacturing sector. The Quarterly Journal of Economics, 123(2), 489-530, 2008. 
Table 1: Descriptive statistics for the key variables

\begin{tabular}{|c|c|c|c|c|c|c|}
\hline Variables & Avg. & Med. & Std. Dev. & Min. & Max. & Obs. \\
\hline \multicolumn{7}{|l|}{ Wage dispersion } \\
\hline r12 & 1.5 & 1.4 & 0.4 & 0.4 & 13.8 & 5,654 \\
\hline r13 & 1.9 & 1.9 & 0.7 & 0.4 & 19.5 & 5,654 \\
\hline $\mathrm{r} 23$ & 1.3 & 1.3 & 0.3 & 0.9 & 12.6 & 5,654 \\
\hline \multicolumn{7}{|l|}{ Wage level (Thou. USD) } \\
\hline New recruit & 24.4 & 23.7 & 6.1 & 4.7 & 109.9 & 5,654 \\
\hline Section chief & 36.1 & 34.1 & 11.3 & 9.5 & 142.2 & 5,654 \\
\hline Department head & 46.6 & 43.7 & 16.7 & 9.5 & 436.4 & 5,654 \\
\hline \multicolumn{7}{|l|}{ Establishment size } \\
\hline Total asset (Mil. USD) & 203 & 134 & 2,810 & 0 & 131,879 & 2,598 \\
\hline Sales (Mil. USD) & 274 & 24 & 2,807 & 0 & 144,996 & 3,549 \\
\hline Number of employees & 340 & 16 & 722 & 3 & 15,250 & 5,654 \\
\hline \multicolumn{7}{|l|}{ Internationalization (\%) } \\
\hline Export proportion & 12.5 & 0 & 23.2 & 0 & 100 & 5,654 \\
\hline Foreigners' ownership share & 5.5 & 0 & 19.1 & 0 & 100 & 5,654 \\
\hline
\end{tabular}

Note: Wages (total asset and sales, respectively) measured in real 2015 Korean wons converted to thousands (millions, respectively) of US dollars.

Table 2: Number of establishments under each internalization category

\begin{tabular}{lccc}
\hline & zero & between 0 and 50 & 50 or more \\
\hline Export proportion & $3,593(63.6 \%)$ & $1,425(25.2 \%)$ & $636(11.2 \%)$ \\
Foreigners' ownership share & $4,882(86.3 \%)$ & $513(9.1 \%)$ & $259(4.6 \%)$ \\
\hline
\end{tabular}


Table 3: Larger wage dispersion at larger and more internationalized establishments

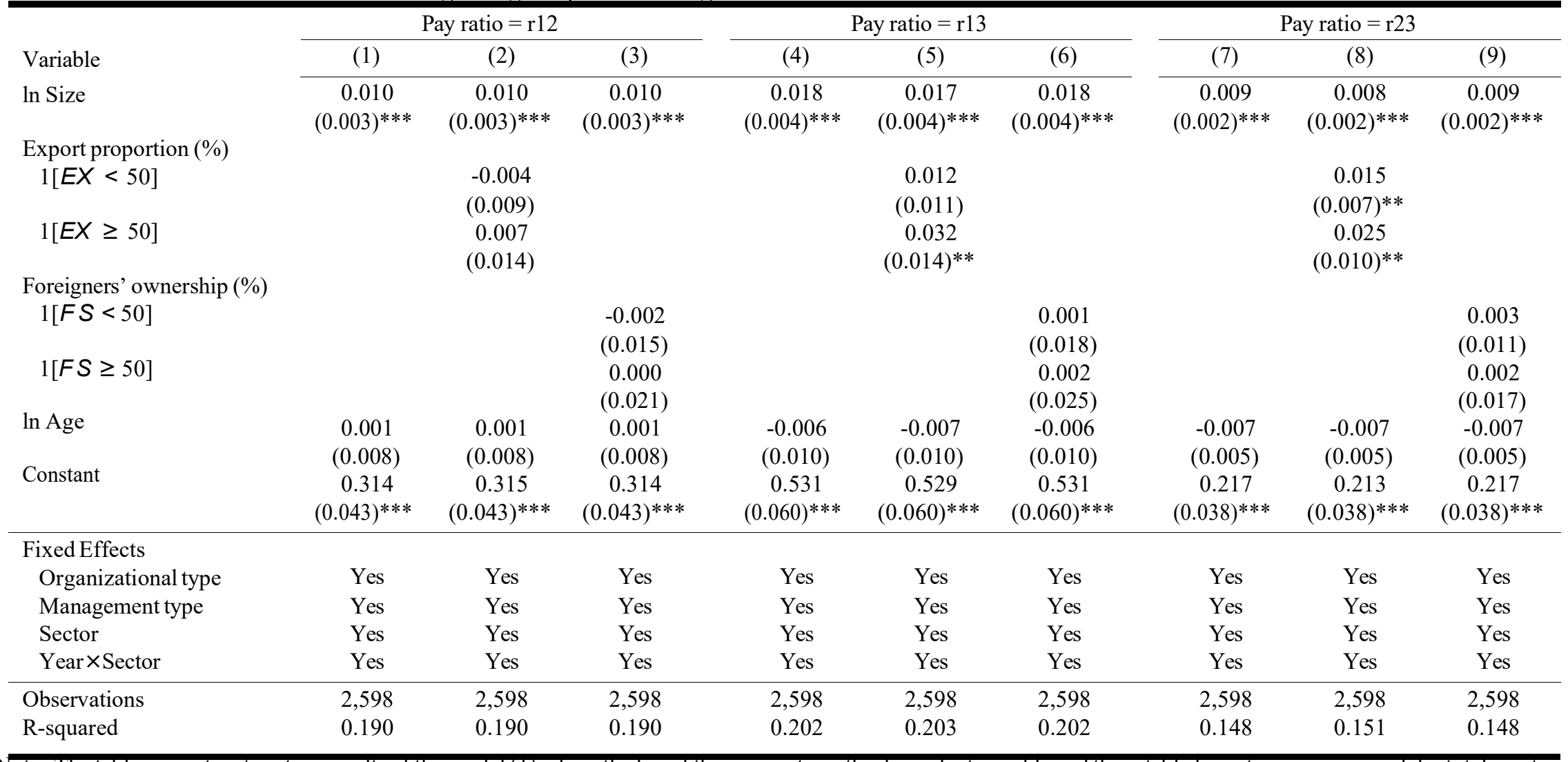

Note: The table presents estimation results of the model(1) where the log of the wage ratio is the dependent variable and the establishment size is measured by total asset.

Robust standard errors (clustered by establishment) are in parentheses. The notation $* * *$ indicates significance at $1 \%$ level, $* *$ at $5 \%$ level,

$*$ at $10 \%$ level. 
Table 4: Higher wage at larger and more internationalized establishments

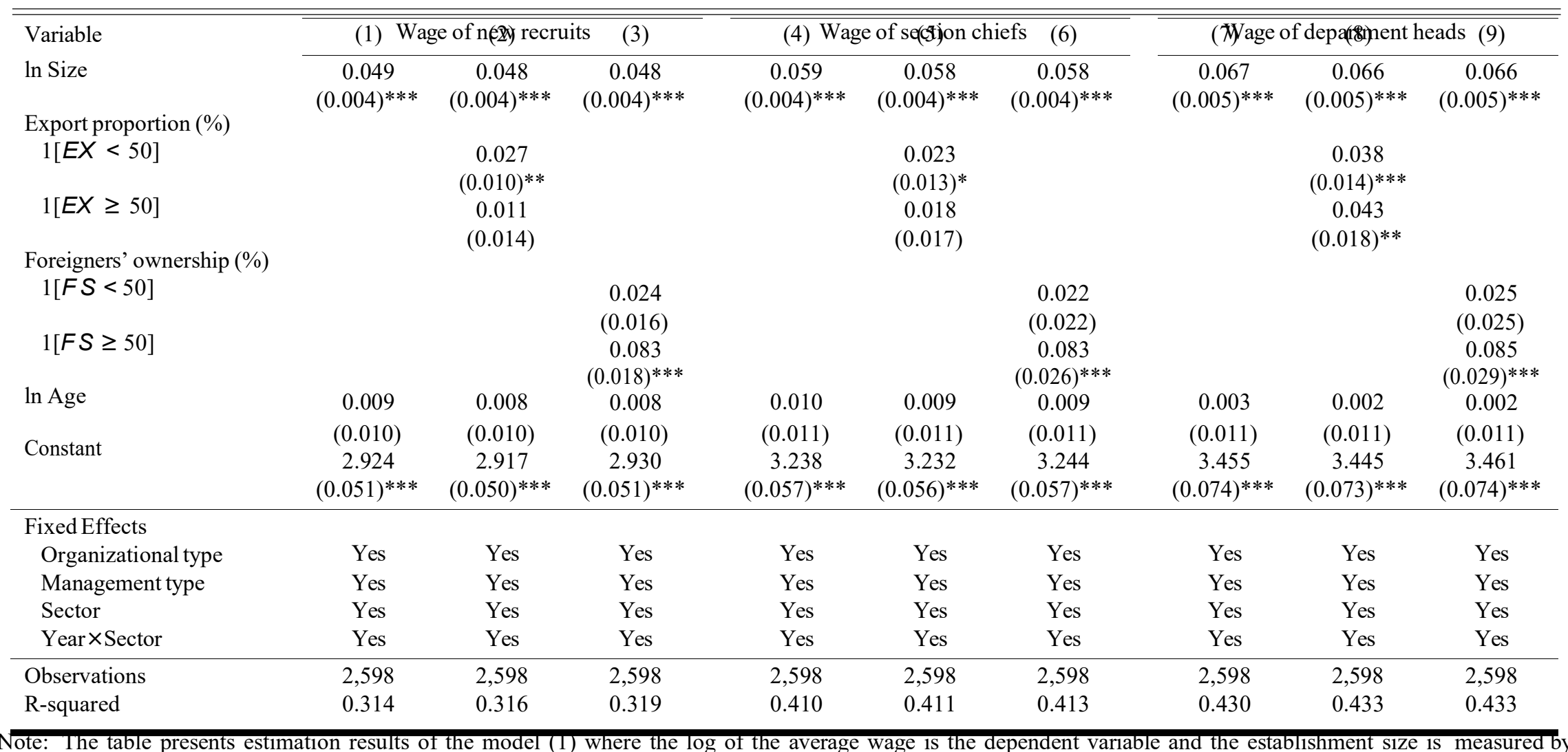

total asset. Robust standard errors (clustered by establishment) are in parentheses. The notation *** indicates significance at $1 \%$ level, $* *$ at $5 \%$ level, * at $10 \%$ level. 
Table 5: Wage dispersion and the growth and internalization of an establishment

\begin{tabular}{|c|c|c|c|c|c|c|c|c|c|}
\hline \multirow[b]{2}{*}{ Variable } & \multicolumn{3}{|c|}{ Pay ratio $=\mathrm{r} 12$} & \multicolumn{3}{|c|}{ Pay ratio $=\mathrm{r} 13$} & \multicolumn{3}{|c|}{ Pay ratio $=\mathrm{r} 23$} \\
\hline & (1) & $(2)$ & (3) & (4) & $(5)$ & (6) & (7) & $(8)$ & (9) \\
\hline $\ln$ Size & $\begin{array}{c}0.008 \\
(0.014)\end{array}$ & $\begin{array}{c}0.008 \\
(0.014)\end{array}$ & $\begin{array}{c}0.008 \\
(0.014)\end{array}$ & $\begin{array}{c}0.035 \\
(0.015)^{* *}\end{array}$ & $\begin{array}{c}0.034 \\
(0.015)^{* *}\end{array}$ & $\begin{array}{c}0.035 \\
(0.015)^{* *}\end{array}$ & $\begin{array}{c}0.027 \\
(0.007)^{* * *}\end{array}$ & $\begin{array}{c}0.027 \\
(0.007)^{* * *}\end{array}$ & $\begin{array}{c}0.027 \\
(0.007)^{* * *}\end{array}$ \\
\hline Export proportion $(\%)$ & & $\begin{array}{c}0.065 \\
(0.037)^{*}\end{array}$ & & & $\begin{array}{c}0.082 \\
(0.037)^{* *}\end{array}$ & & & $\begin{array}{c}0.017 \\
(0.021)\end{array}$ & \\
\hline Foreigners' ownership (\%) & & & $\begin{array}{c}-0.050 \\
(0.052)\end{array}$ & & & $\begin{array}{c}0.019 \\
(0.064)\end{array}$ & & & $\begin{array}{c}0.069 \\
(0.037)^{*}\end{array}$ \\
\hline Constant & $\begin{array}{c}0.391 \\
(0.039)^{* * *}\end{array}$ & $\begin{array}{c}0.383 \\
(0.039)^{* * *}\end{array}$ & $\begin{array}{c}0.395 \\
(0.039)^{* * *}\end{array}$ & $\begin{array}{c}0.568 \\
(0.042)^{* * *}\end{array}$ & $\begin{array}{c}0.557 \\
(0.042)^{* * *}\end{array}$ & $\begin{array}{c}0.567 \\
(0.042)^{* * *}\end{array}$ & $\begin{array}{c}0.177 \\
(0.020)^{* * *}\end{array}$ & $\begin{array}{c}0.174 \\
(0.020)^{* * *}\end{array}$ & $\begin{array}{c}0.172 \\
(0.020)^{* * *}\end{array}$ \\
\hline Fixed Effects & & & & & & & & & \\
\hline Establishment & Yes & Yes & Yes & Yes & Yes & Yes & Yes & Yes & Yes \\
\hline Year $\times$ Sector & Yes & Yes & Yes & Yes & Yes & Yes & Yes & Yes & Yes \\
\hline Observations & 2,598 & 2,598 & 2,598 & 2,598 & 2,598 & 2,598 & 2,598 & 2,598 & 2,598 \\
\hline
\end{tabular}

Note: The table presents estimation results of the model(1) where the log of the wage ratio is the dependent variable and the establishment size is measured by total asset.

Establishment fixed effects are used instead of the sector fixed effects. Robust standard errors (clustered by establishment) are in parentheses. The notation $* * *$ indicates

significance at $1 \%$ level, $* *$ at $5 \%$ level, * at $10 \%$ level. 
Table 6: Wage level and the growth and internalization of an establishment

\begin{tabular}{|c|c|c|c|c|c|c|c|c|c|}
\hline \multirow[b]{2}{*}{ Variable } & \multicolumn{3}{|c|}{ Wage of new recruits } & \multicolumn{3}{|c|}{ Wage of section chiefs } & \multicolumn{3}{|c|}{ Wage of department heads } \\
\hline & (1) & (2) & (3) & (4) & (5) & $(6)$ & (7) & $(8)$ & (9) \\
\hline \multirow[t]{2}{*}{$\ln$ Size } & 0.000 & 0.000 & 0.001 & 0.008 & 0.008 & 0.009 & 0.035 & 0.035 & 0.036 \\
\hline & $(0.011)$ & $(0.011)$ & $(0.011)$ & $(0.012)$ & $(0.012)$ & $(0.012)$ & $(0.012)^{* * *}$ & $(0.012)^{* * *}$ & $(0.012)^{* * *}$ \\
\hline \multirow[t]{2}{*}{ Export proportion (\%) } & & 0.002 & & & 0.067 & & & 0.084 & \\
\hline & & $(0.035)$ & & & $(0.036)^{*}$ & & & $(0.036)^{* *}$ & \\
\hline \multirow[t]{2}{*}{ Foreigners' ownership (\%) } & & & 0.083 & & & 0.033 & & & 0.102 \\
\hline & & & $(0.055)$ & & & $(0.065)$ & & & $(0.080)$ \\
\hline \multirow[t]{2}{*}{ Constant } & 3.109 & 3.109 & 3.104 & 3.501 & 3.492 & 3.499 & 3.677 & 3.666 & 3.671 \\
\hline & $(0.032)^{* * *}$ & $(0.031)^{* * *}$ & $(0.032)^{* * *}$ & $(0.032)^{* * *}$ & $(0.033)^{* * *}$ & $(0.032)^{* * *}$ & $(0.034)^{* * *}$ & $(0.034)^{* * *}$ & $(0.034)^{* * *}$ \\
\hline \multicolumn{10}{|l|}{ Fixed Effects } \\
\hline Establishment & Yes & Yes & Yes & Yes & Yes & Yes & Yes & Yes & Yes \\
\hline Year $\times$ Sector & Yes & Yes & Yes & Yes & Yes & Yes & Yes & Yes & Yes \\
\hline Observations & 2,598 & 2,598 & 2,598 & 2,598 & 2,598 & 2,598 & 2,598 & 2,598 & 2,598 \\
\hline
\end{tabular}

Note: The table presents estimation results of the model(1) where the log of the average wage is the dependent variable and the establishment size is measured by total asset. Establishment fixed effects are used instead of the sector fixed effects. Robust standard errors (clustered by establishment) are in parentheses. The notation ***

indicates significance at $1 \%$ level, ** at $5 \%$ level, * at $10 \%$ level. 
Table 7: Larger wage dispersion at larger and more internationalized establishments using sales

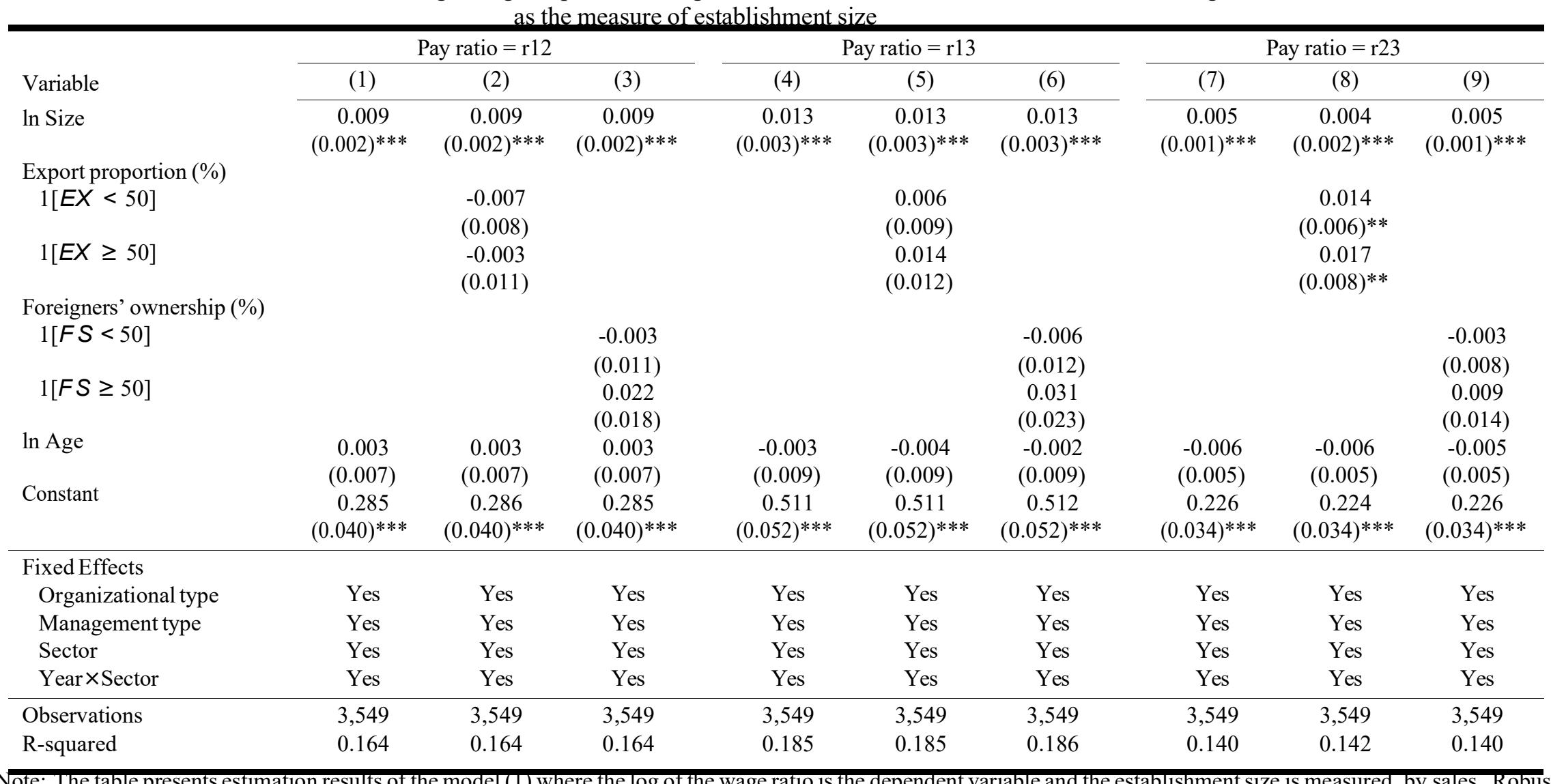

standard errors (clustered by establishment) are in parentheses. The notation $* * *$ indicates significance at $1 \%$ level, ** at $5 \%$ level, * at $10 \%$ level. 
Table 8: Higher wage at larger and more internationalized establishments using sales as the measurement of establishment size

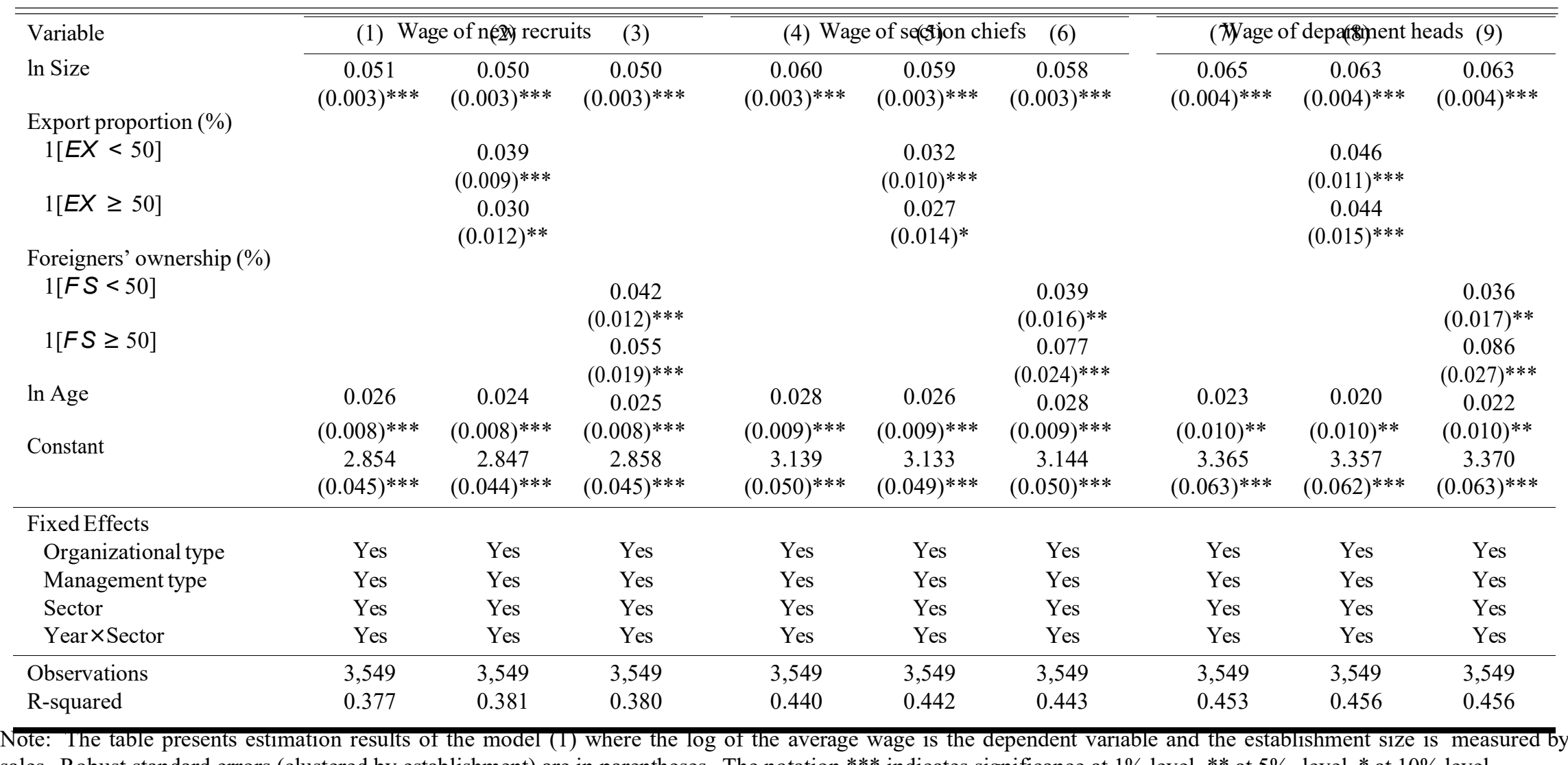

sales. Robust standard errors (clustered by establishment) are in parentheses. The notation *** indicates significance at $1 \%$ level, $* *$ at $5 \%$ level, * at $10 \%$ level. 
Table 9: Larger wage dispersion at larger and more internationalized establishments using number of emplovees as the measure of establishment size

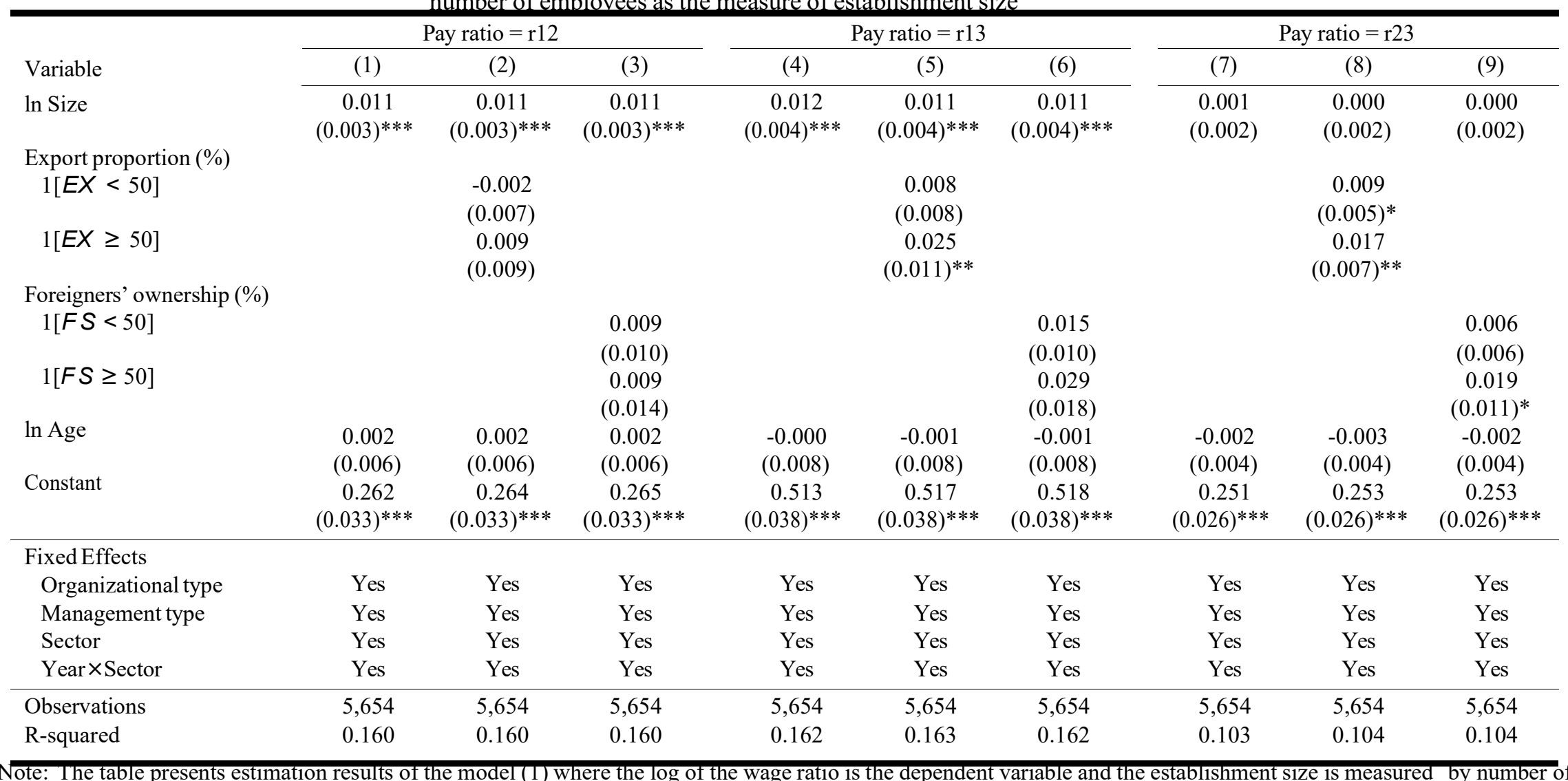

employees. Robust standard errors (clustered by establishment) are in parentheses. The notation *** indicates significance at $1 \%$ level, $* *$ at $5 \%$ level, * at $10 \%$ level. 
Table 10: Higher wage at larger and more internationalized establishments using number of employees as the measurement of establishment size

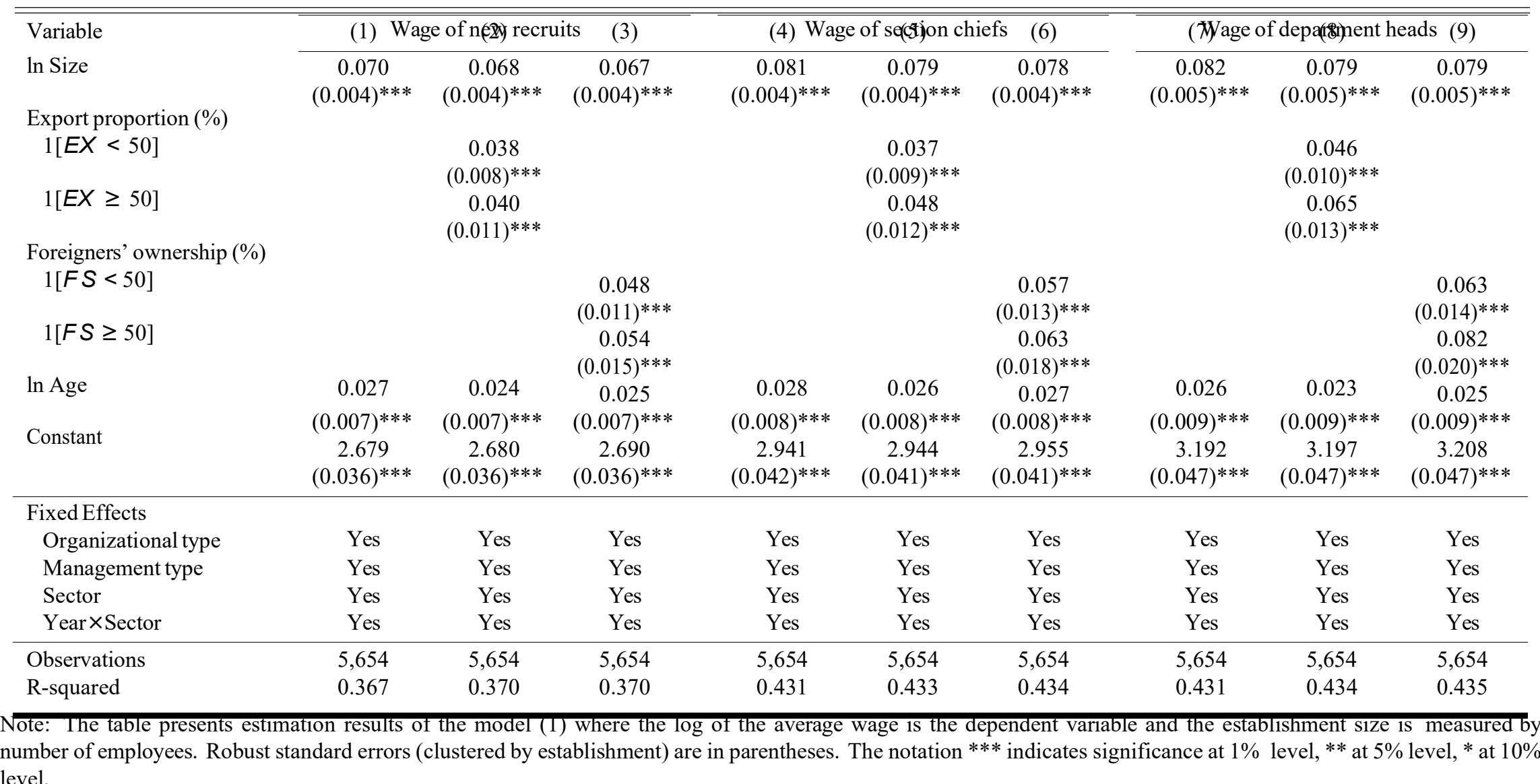

level. 
Table 11: Larger wage dispersion at larger and more internationalized establishments dropping

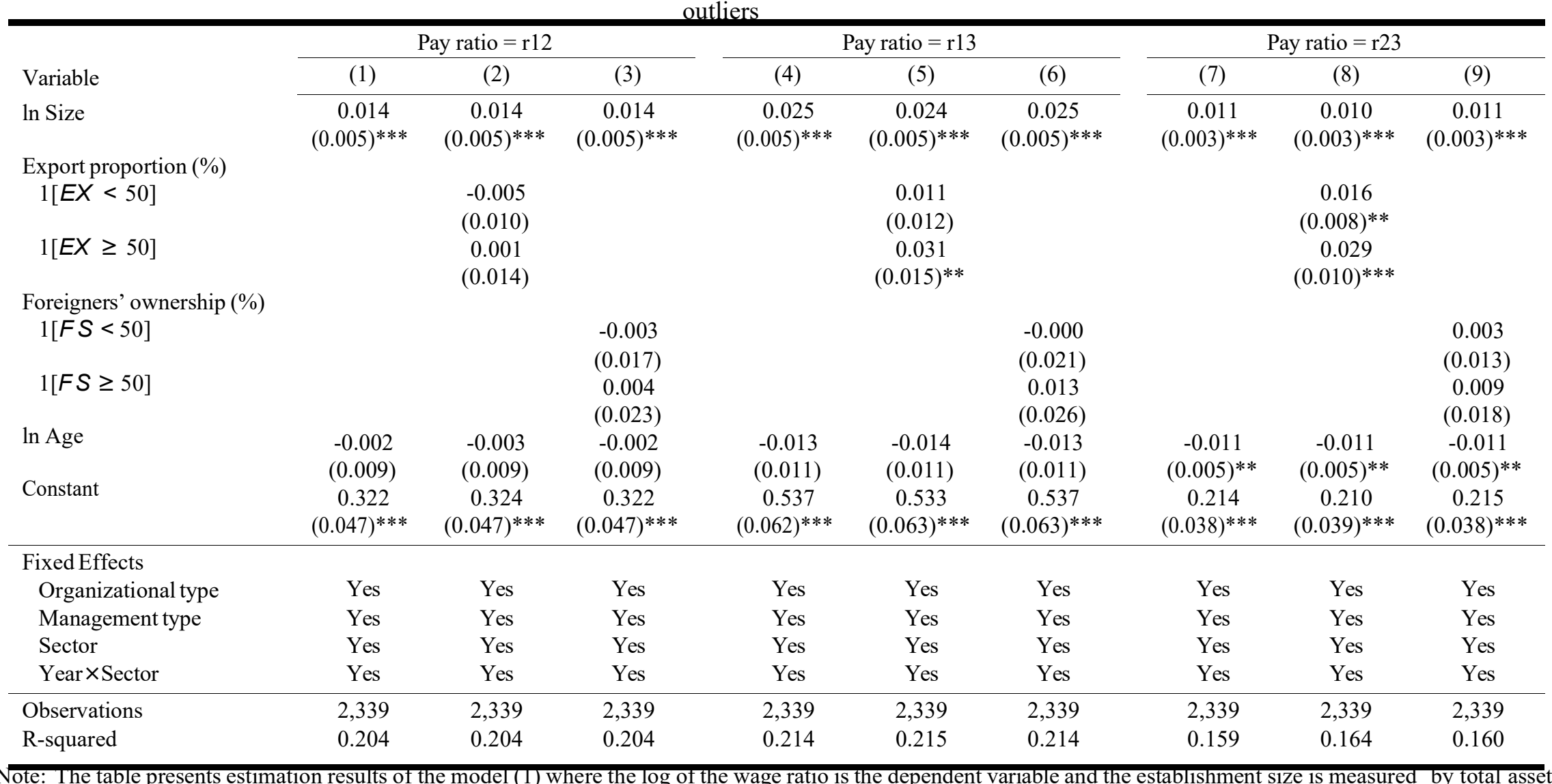

Observations that belong to the lower and upper 5 percentile in terms of the total asset are dropped. Robust standard errors (clustered by establishment) are in parentheses. The notation $* * *$ indicates significance at $1 \%$ level, $* *$ at $5 \%$ level, $*$ at $10 \%$ level. 
Table 12: Higher wage at larger and more internationalized establishments dropping outliers

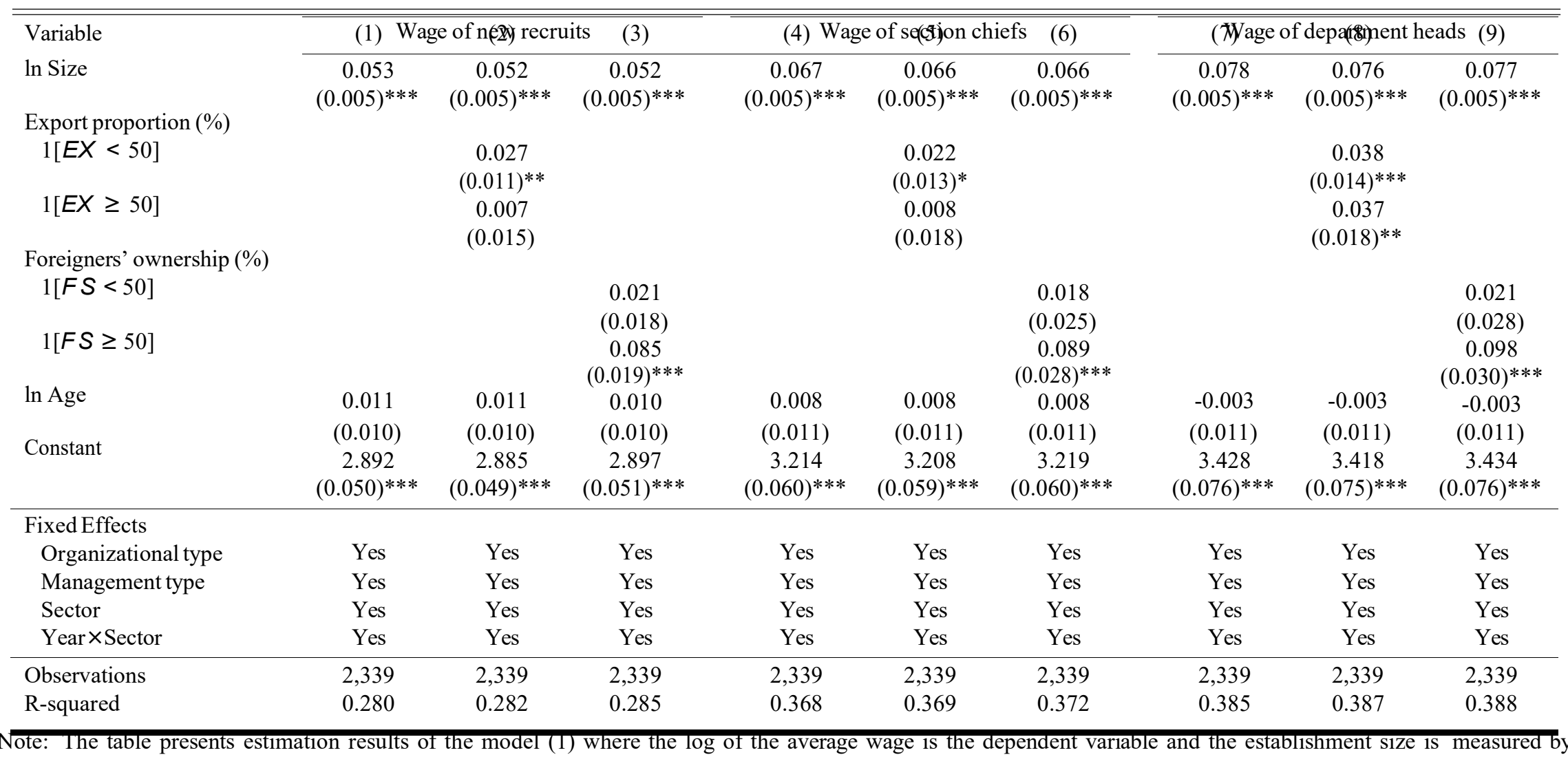

total asset. Observations that belong to the lower and upper 5 percentile in terms of the total asset are dropped. Robust standard errors (clustered by establishment) are in parentheses. The notation $* * *$ indicates significance at $1 \%$ level, ** at $5 \%$ level, * at $10 \%$ level. 


\section{Data Appendix}

Whereas the number of employees is establishment level and available for all establishments in the data, total asset and sales are firm level and missing for some observations (1,544 for asset and 1,386 for sales out of 7,017 observations). For single establishment firms, they can be considered as establishment level. ${ }^{11}$ For establishments that belong to multiple establishment firms, we compute the establishment level sales as the product of firm level sales and the proportion of the establishment sales in total sales of the firm. This can be done only for 1,001 observations of those establishments that report their sales proportions in the survey.

We drop the following observations from the analysis: (1) 788 observations in electricity/gas, fi- nancial, public sectors as their wages are firm level, not establishment level, (2) 549 observations with missing wage information, and (4) 26 observations whose reported asset or sales is zero. After removing them, we have 5,654 observations from 2,116 establishments available for the analysis. While 48.7 per- cent of the establishments in the sample data belong to manufacturing sector, examples of other sectors include transportation (9.3 percent), retailing ( 7 percent), and construction (5.8 percent).

\footnotetext{
${ }^{11} 63$ percent of the 2,438 establishments in the data are single establishments.
} 